\title{
Non-antibiotic treatment of equine endometritis
}

\author{
Mats H. T. Troedsson ${ }^{1,3}$ and Jesper Møller Nielsen ${ }^{2,3}$ \\ ${ }^{1}$ Maxwell H. Gluck Equine Research Center, University of Kentucky, KY \\ ${ }^{2}$ Ansager Dyrehospital, Ansager, Denmark \\ ${ }^{3}$ Equine Veterinary Medical Center, Al Shaqab/Qatar Foundation, Doha, Qatar
}

\begin{abstract}
Summary: Equine endometritis is an important cause of infertility, associated with major economic losses to the horse industry worldwide. An evolving understanding of the complexity of the disease has resulted in new treatment approaches to combat the effect on fertility through alternative non-antibiotic therapies. The objective of this article is to review some of the commonly used non-antibiotic treatment options for equine endometritis. The most recent literature on treatment options with non-antibiotic antimicrobials, immune-modulators, ecbolics and other treatments such as uterine lavage and stem cell therapy is reviewed. It is concluded that a great variety of treatment options are available to the clinician, but only a few have been tested and proven beneficial under controlled conditions. Fashionable treatments that are used without having been critically tested may represent a potential threat to the integrity of the veterinary profession, and the clinician should at a minimum have sufficient information to support the safety of the product, both for the horse and the health of the endometrium.
\end{abstract}

Keywords: endometritis, horse, equine, non-antibiotic, treatment

Citation: Troedsson M. H. T., Møller Nielsen J. (2018) Non-antibiotic treatment of equine endometritis. Pferdeheilkunde 34, 17-22; DOI DOI 10.21836/PEM20180103

Correspondence: Mats H.T. Troedsson, Maxwell H. Gluck Equine Research Center, University of Kentucky, KY

\section{Introduction}

Equine endometritis is an important cause of infertility, associated with major economic losses to the horse industry worldwide. Past research has brought new information on the underlying causes of persistent inflammation and highlighted failures of the uterine defense mechanisms in horses that are classified as susceptible to persistent endometritis (Troedsson 1999). We have also learned that endometritis can be caused by either an infection with bacteria/fungus/ yeast, or semen associated with breeding. The two causative forms of endometritis require different treatment approaches. While local and/or systemic antibiotics based on microbial sensitivity may be the most effective treatment for infectious endometritis, this therapeutic approach is less likely to resolve a persistent uterine inflammation in mares with breeding-induced endometritis (Troedsson and Woodward 2016). Research data suggest that susceptibility to persistent endometritis involves a failure of uterine defense mechanisms at multiple levels (Troedsson and Woodward 2016). Anatomical defects of the perineal confirmation, the vestibule-vaginal fold, the cervix, and a tilted position of the uterus in the abdomen have all been associated with persistent endometritis (Hemberg et al. 2005). Without correction of physical defects, any treatment of endometritis would only represent a temporary solution. Insufficient physical clearance of the uterus caused by impaired myometrial activity in response to an inflammation has also been shown to cause susceptibility to persistent endometritis in response to bacterial contamination as well as semen during breeding (Troedsson 1999). Earlier research on the local uterine immune system produced conflicting and nonconclusive data regarding a possible involvement of a deficient cellular and humoral immune defense in the development of persistent endometritis (Asbury et al. 1982, Troedsson 1999). More recently, the innate immune system, particularly cytokine expression in response to bacteria as well as semen has been investigated by several research groups (Fumoso et al. 2003, Christoffersen et al. 2012, Woodward et al. 2013, Marth et al, 2015). The overall conclusion of this published data is that the development of persistent endometritis is associated with an imbalance of pro-inflammatory cytokines and inflammatory modulating cytokines in response to a bacterial or seminal challenge. A report by Woodward et al. (2013) suggests that the imbalance is present already within $3-6$ hours after insemination in susceptible mares. The increased understanding of the pathophysiology of equine endometritis has resulted in new and suggested therapeutically approaches to the problem. While many treatment regimens have been, and currently are used in veterinary practice, there is limited data in support of efficacy as well as safety of these treatment options. The objective of this article is to review some of the commonly used non-antibiotic treatment options for equine endometritis.

\section{Antimicrobial effects}

While suitable antibiotics are the most effective treatment against infectious endometritis, recent research has been focused on situations where this treatment alone is not sufficient to eliminate bacterial growth from the uterus. Suggested presence of biofilms, dormant bacteria in the deeper layers of the endometrium, and other barriers may prevent antibiotics to reach their target and effectively eliminate bacteria (GoresLindholm et al. 2013, Petersen et al. 2015, Ferris et al. 2016). Although further evidence may be needed to conclusively confirm some of these hypotheses, their suggestive presence in the uterus have given rise to multiple treatment options to accompany or replace traditional antibiotics. The medical value of most of these treatments is often anecdotal, rather than evidence based. 


\section{N-Acetylcysteine (NAC)}

This mucolytic substance has been used to reduce the viscosity of mucus in the uterus. In addition NAC has been suggested to have anti-inflammatory/ antioxidant and antibacterial activity (Zuin et al. 2005). Typically, $30 \mathrm{~mL}$ of a $20 \%$ solution NAC $(200 \mathrm{mg} / \mathrm{mL})$ is diluted in $150 \mathrm{~mL}$ of saline and infused into the uterine lumen during estrus, followed by ecbolic treatment or uterine lavage 12 hours after treatment. The treatment protocol has been suggested to be beneficial both 24-48 hours prior to breeding and 24 hours prior to antibiotic treatment. Repeated lavage may be indicated if the effluent fluid is cloudy (LeBlanc nad McKinnon 2011 ). When used together with antibiotics, the interaction with antimicrobials should be kept in mind. NAC enhances the efficacy of $\beta$-lactams, but reduces the anti-bacterial activity of aminoglycosides, fluoroquinolones and erythromycin. Oral treatment with NAC at $10 \mathrm{mg} / \mathrm{kg}$ did not reduce viscosity of uterine mucus; however an anti-inflammatory effect was observed in one study (Witte et al 2012). NAC was also suggested to decrease biofilm biomass and reduce bacteria within biofilms of $\mathrm{E}$. Coli isolates in vitro (Ferris et al. 2016). The same effect was however, not observed for other bacteria. Intrauterine treatment with NAC is sufficiently proven to be safe, and has been suggested to improve pregnancy rates, although the pregnancy data was not supported by controlled experimental conditions (Gores-Lindholm et al. 2013).

\section{EDTA-tris}

Tricide $^{\circledR}$ (a third generation chelator) chelates calcium and magnesium within the bacterial cell wall, which may potentiate the effect of antibiotics (Lyle et al. 2011 ). It has been suggested to potentiate the effect of antibiotics on some bacteria, but its effect to disrupt gram negative biofilms is less clear (Ferris et al. 2016). Treatment protocols often consist of intra uterine infusions of 500-1000 mL Tricide, followed by uterine lavage with a buffered saline solution the following day. The treatment is repeated until the effluent fluid is clear, at which time the mare is treated with local antibiotics for 5 days. Tricide can also be added to antibiotics, but is not recommended to be used together with ceftiofur, K-penicillin or Timentin due to precipitation in the solution (LeBlanc and McKinnon 2011).

\section{Cationic Steroid Antimicrobial (CSA)}

Ceragyn ${ }^{\circledR}$ belongs to a class of peptides that cause depolarization of bacterial cell wall membranes and activate apoptotic pathways. These peptides have been used for various conditions in human medicine because of their biofilm breakdown and broad spectrum anti-microbial activities. Ceragyn (60 mL; 1 vial) is labeled for use up to 24 hours before or $12-48$ hours after breeding. The drug has become increasingly popular among equine practitioners but the authors have not been able to find conclusive data from controlled studies to support its effect on equine endometritis.

\section{Hydrogen peroxide}

$\mathrm{H}_{2} \mathrm{O}_{2}$ has a bactericidal effect on most uterine pathogens. A $1 \%$ solution $\left[20 \mathrm{~mL}\right.$ of a $3 \% \mathrm{H}_{2} \mathrm{O}_{2}$ solution diluted in $60 \mathrm{~mL}$ lactated Ringer solution (LRS)] has been suggested to be effective on biofilms in vitro (Ferris et al. 2016). Information regarding the efficacy of $\mathrm{H} 2 \mathrm{O} 2$ treatment is anecdotal, and needs to be supported by controlled in vivo studies.

\section{bActivate}

A proprietary substance marketed as bActivate ${ }^{\circledR}$ has been shown to activate dormant Streptococcus from the equine endometrium (Petersen et al. 2015). Dormant bacteria are not sensitive to antibiotics, but following confirmed activation with bActivate ${ }^{\circledR}$, evident by a positive culture, mares can successfully be treated with intrauterine infusion of antibiotics. Fertility data from controlled studies are however, needed to confirm claims of improved fertility following treatment.

\section{Immune-modulators}

The immune response of the equine endometrium has been investigated following bacterial inoculation as well as following insemination (Christoffersen et al. 2012, Woodward et al. 2013). Treatment protocols aimed at restoring a normal immune response in susceptible mares after bacterial infection and/or breeding have been reported.

\section{Corticosteroid}

Several studies support a positive clinical effect of corticosteroids on persistent breeding-induced endometritis (PBIE). A single dose of dexamethasone $150 \mathrm{mg}$ at the time of breeding) was found to improve pregnancy rates in mares with more than 3 risk factors for susceptibility to PBIE (Bucca et al. 2008). Researchers from Belgium did not observe a positive effect of treatment with $10 \mathrm{mg}$ or $20 \mathrm{mg}$ of dexamethasone 6-12 hours after $\mathrm{Al}$ in a large group of unclassified mares (Vandaele et al. 2008). However, mares with a history of excessive post-breeding inflammation had significantly higher pregnancy rates when treated with acetate 9 - $\alpha$-prednisolone $(0.1 \mathrm{mg} / \mathrm{kg})$ twice daily when compared to control cycles (Dell'Aqua et al. 2004). An effect of corticosteroids on the innate uterine immune response as well as the uterine environment has been reported by several authors (Woodward et al. 2013, Christoffersen et al. 2012, Arlas et al. 2015). Although the immune modulation appears to favor resolution of inflammation, it does not mimic that of resistant mares.

\section{Non-steroid anti-inflammatory drugs (NSAID)}

Because of its modulating effect on inflammation, treatment of susceptible mares with NSAIDs has been studied (Rojer and Aurich 2010). Oral administration of Vedaprofen $(2 \mathrm{mg} / \mathrm{kg})$ the day before $\mathrm{Al}$, and $1 \mathrm{mg} / \mathrm{kg}$ twice daily until one day after ovulation, had no effect on fluid accumulation or uterine cytology, but resulted in a higher pregnancy rates. It should be noted that the mares were also treated with oxytocin $(20 \mathrm{IU})$ three times per day. More research is needed to determine the potential value of this treatment protocol. 


\section{Bacterial Cell-Wall Extracts}

Cell wall extracts of Mycobacterium Phlei (MCWE) as well as Propionibacterium Acnes have been investigated regarding their effect on the uterine immune system as well as reproductive performance. Fumoso et al. (2003) found that MCWE treatment of susceptible mares at the time of breeding resulted in an endometrial immune environment similar to that of resistant mares at 24 hours after $\mathrm{Al}$. In a follow-up study, the authors concluded that MCWE treatment was effective in eliminating inoculated bacteria from the uterus in $70 \%$ of treated mares at 7 days after infusion (Rogan et al. 2007). In another report by Christoffersen et al. (2012), studying the immune response between 3 and 72 hours after intrauterine inoculation of E. Coli, cytokine expression in MCWE treated mares was not different from untreated mares, but mRNA expression of SAA was suppressed in treated mares. Clinically, MCWE had a favorable effect in the clearance of pathogens and fluid retention (Christoffersen et al. 2012). Studying the immune response to semen, Woodward et al. (2013) found that MCWE down regulated mRNA expression of IL- 1 in susceptible mares at 6 hours after Al, supporting previous observations by Fumoso et al (2007). A comprehensive clinical study suggested that treatment of problem mares with Propionibacterium Acnes extract $\left(\right.$ Settle ${ }^{\circledR}$ ) resulted in a $10 \%$ increase in pregnancy rates compared to untreated controls (Rohrbach et al. 2006). However, the mares received additional treatments and the effect of stallion fertility was not considered under the condition of the study.

\section{Plasma}

Intrauterine infusion of autologous or heterologous plasma has been used in the past to treat mares with infectious endometritis (Asbury 1984). The rationale for the treatment was to add immunoglobulins and complement to assist the mares in eliminating pathogens from the uterus. Supplementation of fresh or cryopreserved PMNs into the uterine lumen in mares with persistent endometritis has also been proposed as an alternative treatment to antibiotics (Zerbe et al. 2003, Mattos et al. 1999, Neves et al. 2007). More recent use of plasma products has been directed towards immunomodulation rather than elimination of pathogens from the uterus. Platelet Rich Plasma (PRP) was shown to modulate the uterine inflammatory response to semen (Reghini et al. 2016, Segabinazzi et al. 2017), including mRNA down regulation of pro-inflammatory cytokines and $\mathrm{NO}$ in one study (Metcalf et al. 2012). The downregulation of $\mathrm{NO}$ was initially viewed as promising, since an upregulation of $\mathrm{NO}$-synthase and accumulation of $\mathrm{NO}$ in uterine fluid in susceptible mares had been proposed as a possible mechanism for impaired uterine contractility in susceptible mares (Alghamdi et al. 2005, Woodward et al. 2013). However, subsequent studies could not confirm that PRP caused a consistent downregulation of the gene for NO-synthase or NO (Reghini et al. 2016, Troedsson, unpublished observation). Nevertheless, clinical reports have been encouraging, suggesting improved pregnancy rates in mares treated with PRP (Metcalf 2014, Segabinazzi et al. 2017). The protocol for treatment with PRP entails separation of $180 \mathrm{~mL}$ of whole blood by a special centrifugation system (Angel Cytomedix, Inc.; Gaithersburg, MD), followed by resuspension of the PRP in
$10 \mathrm{~mL}$ plasma succeeding uterine infusion 24-36 hours prior to breeding.

\section{Lactoferrin}

Infectious endometritis has been associated with endometrial expression of lactoferrin in broodmares (Christoffersen and Nielsen 2015). A recent study in our laboratory (Fedorka et al. unpublished) showed that human recombinant lactoferrin ( $h r L F)$, is safe to administer in the equine uterus and modulates breeding induced inflammation through a decreased in PMNs, as well as an upregulation of the modulatory cytokine IL- 1RN and a down regulation of IFN. It was concluded that intrauterine treatment with $250 \mathrm{vg} / \mathrm{mL}$ hrLF may assist susceptible mares to resolve the breeding induced inflammation in a timely fashion. Clinical trials are needed to confirm this hypothesis.

\section{Ecbolics}

The administration of ecbolic drugs after breeding is effective in overcoming impaired myometrial contractility in susceptible mares (LeBlanc et al. 1994, Troedsson 1995, Troedsson et al. 2005).

\section{Oxytocin}

Generally, low doses of oxytocin appear to be more effective than high doses (Campbell and England 2002). A common treatment protocol is 10-20 IU of oxytocin 4-6 hours after breeding, repeated every $6-8$ hours until the intraluminal fluid has disappeared. The half-life of oxytocin is relatively short, resulting in approximately 50 minutes of myoelectric activity after the administration of $10 \mathrm{IU}$ (Madill et al. 2002).

\section{Carbetocin}

Carbetocin is a long acting oxytocin analogue with an extended half-life after intravenous administration of $0.175 \mathrm{mg}$ IV (Schramme et al. 2008). Limited data is available on the efficacy of carbetocin versus oxytocin.

\section{PGF2a}

PGF2 $\alpha$ has considerably longer duration on uterine contractility compared to oxytocin (Troedsson et al. 2001). Treatment is not recommended after ovulation, since PGF2 $\alpha$ and its analogues can cause a delay in the formation of a functional $C L$ when administered within 2 days after ovulation (Troedsson et al. 2001). It is the authors' observation that luteolytic doses of PGF2 $\alpha$ are excessive and may cause myometrial "cramp" initially, rather than a physiological contraction that would be more suitable to remove fluid from the uterus. A suitable dose of PGF2 $\alpha$ and its analogues for treatment of equine endometritis has not been established. In severe cases of persistent breeding induced endometritis, ecbolic treatment is often combined with uterine lavage with $1-2 \mathrm{~L}$ of buffered saline 6-12 hours after breeding (LeBlanc and McKinnon 2011). 
Social interaction with a stallion: Social interaction with a stallion may facilitate normal uterine clearance following breeding. Audio, visual and physical exposure of mares to a stallion stimulated pituitary oxytocin release and caused uterine contractions (Madill et al. 2000). This observation has been confirmed in a subsequent report (Lyle et al. 2014). Housing susceptible mares close to a tease stallion after breeding may therefore enhance normal uterine activity and clearance.

\section{Other}

\section{Uterine lavage}

Infusion of $1-2 \mathrm{~L}$ buffered saline solution or LRS at 6 hours after breeding, or prior to treatment with antibiotics in cases of chronic infectious endometritis, is effective in removing accumulated fluid and inflammatory products from the uterus. The uterine lavage is typically repeated until the recovered effluent fluid is clear. The treatment is often combined with an ecbolic drug in order to facilitate recovery of the infused fluid (Troedsson et al. 1995, Mattos et al. 1999, LeBlanc and McKinnon 2011).

\section{Stem cells}

The use of mesenchymal autologous stem cells and autologous conditioned serum has been explored in experimental models as potential treatment alternatives for susceptible mares and mares with degenerative endometrosis (Ferris et al. 2014, Mambelli et al. 2014, Corradetti 2014, Alvarenga et al. 2016). A modulation of the inflammatory response to semen has been reported as well as indication that regenerative treatment strategies have the potentials to restore degenerative changes to the endometrium. More research is expected in this area.

\section{Additional}

In addition to the mentioned treatments, numerous agents have been used to treat equine endometritis, including dimethyl sulfoxide (DMSO), kerosene, magnesium sulphate, Streptococcus filtrate, and dilute disinfectants (chlorhexidine, povidone-iodine). Reports on the efficacy of these agents is anecdotal, and it should be kept in mind that many are irritant to the endometrium and may cause more harm than good if not used with great restriction.

\section{Conclusion}

A variety of non-antibiotic treatment options are available to the clinician, but only a few have been tested and proven beneficial under controlled conditions. The clinician should at a minimum have sufficient information on safety of the treatment and its effect on the endometrium before implementing a treatment regimen. It should also be remembered that semen is the best single treatment of infertility, and only $10-15 \%$ of brood mares need help to assist the uterus to provide a healthy environment after breeding.

\section{Conflict of interest}

None

\section{References}

Alghamdi A. S., Foster G. N., Troedsson M. H. T. (2005) Nitric oxide levels and nitric oxide synthase expression in uterine samples from mares susceptible and resistant to persistent breeding-induced endometritis. Am. J. Reprod. Immunol. 53, 230-237

Arlas T. R., Wolf C. A., Petrucci B. P., Estaislau J. F., Gregory R. M., Jobim M. I., Mattos R. C. (2015) Proteomics of endometrial fluid after dexamethasone treatment in mares susceptible to endometritis. Theriogenology 84, 617-623

Asbury A. C. (1984) Uterine defense mechanisms in the mare: The use of intrauterine plasma in the management of endometritis. Theriogenology 21, 387-393

Asbury A. C., Schultz P. H., Klesius G. N., Foster G. N., Washburn S. M. (1982) Feactors affecting phagocytosis of bacteria and neutrophils in the mares uterus. J. Reprod Fert. (Suppl) 32, 151-159

Bucca S., Carli A., Buckley T., Dolci G., Fogarty U. (2008) The use of dexamethasone administered to mares at breeding time in the modulation of persistent mating induced endometritis. Theriogenology 64, 1093-1100

Campbell M. L. H, England G. C. W. (2002) A comparison of the ecbolic efficacy of intravenous and intrauterine oxytocin treatments. Theriogenology 58, 473-477

Christoffersen M., Woodward E., Bojesen A. M., Jacobsen S., Petersen M. R., Troedsson M. H. T., Lehn-Jensen H. (2012) Inflammatory responses to induced infectious endometritis in mares resistant or susceptible to persistent endometritis. BMC Vet. Res. 8, 41; DOI 10.1186/1746-6148-8-41

Christoffersen M., Woodward E. M., Bojesen A. M., Petersen M. R., Squires E. L., Lehn-Jensen H., Troedsson M. H. T. (2012) Effect of immunomodulatory therapy on the endometrial inflammatory response to induced infectious endometritis in susceptible mares. Theriogenology 78, 991-1004

Christoffersen M., Nielsen J. M. (2015) Infectious endometritis is associated with endometrial expression of lactoferrin in broodmares. Abstract, International Congress on Biology and Pathology of Reproduction in Domestic Animals. Gdansk, September 28th 2015

Corradetti B., Correani A., Romaldini A., Marini M.G., Bizzaro D., Perrini C., Cremonesi F., Lange-Consiglio A. (2014) Amniotic membrane-derived mesenchymal cells and their conditioned media: potential candidates for uterine regenerative therapy in the horse. PLoS One 31, 9:e 111324

Dell'Aqua Jr. J. A., Papa F. O., Lopes M. D., Alvarenga M. A., Macedo L. P., Neves Neto J. R. (2004) Fertility rates with equine frozen semen after modulation of inflammatory uterine response. In: Proc 15th Int. Cong. Anim. Reprod. 2004. p. 391

Ferris R. A., McCue P. M., Borlee G. I., Loncar K. D., Hennet M. L., Borlee B. R. (2016) In vitro efficacy of Nonantibiotic treatments of biofilm disruption of gram-negative pathogens and an in vivo model of infectious endometritis utilizing isolates from the equine uterus. J. Clin. Microb. 54, 631-639

Fumoso E., Giguere S., Wade J., Rogan D., Videla-Dorna I., Bowden R. A. (2003) Endometrial IL-beta, IL-6 and TNF-alpha mRNA expression in mares resistant or susceptible to post-breeding endometritis. Effects of estrous cycle, artificial insemination and immunomodulation. Vet. Immun. Immunopath. 96, $31-41$

Fumoso E. A., Aguilar J., Giguere S., Rivulgo M., Wade J., Rogan D. (2007) Immune parameters in mares resistant and susceptible to persistent post-breeding endometritis: effect of immunomodulation. Vet. Immun. An. Immunopath. 1 18, 30-39

Gores-Lindholm A. R., leBlanc M. M., Causey R., Hitchborn A., Fayrer-Hosken R. A., Kruger M., Vandenplas M. L., Flores P., Ahlschwede S. (2013) Relationships between intrauterine infusion of $\mathrm{N}$-acetylcysteine, equine endometrial pathology, neutrophil function, post-breeding therapy, and reproductive performance. Theriogenology $80,218-227$ 
Hemberg E., Lundeheim N., Einarsson S. (2005) Retrospective study on vulvar conformation in relation to endometrial cytology and fertility in Thoroughbred mares. J. Vet. Med. 52, 474-477

LeBlanc M. M., Neuwirth L., Mauragis D., Klapstein E., Tran T. (1994) Oxytocin enhances clearance of radiocolloid from the uterine lumen of reproductively normal mares and mares susceptible to endometritis. Equine Vet. J. 26, 279-282

LeBlanc M. M., McKinnon A. O. Breeding the problem mare. In: McKinnon A. O., Squires E. L., Vaala W. E., Varner D. D. (2011) Eds. Equine Reproduction 2nd ed. Wiley Blackwell, West Sussex, UK. p. 2620.

Lyle S. K., LeBlanc M. M., Staepfli S. A., Beehan D. P., Morgan T. (2011) How to use buffered chelator solution for mares with chronic endometritis. Proceedings Am. Assoc. Equine Pract. 57, 16-18

Lyle S. K., Durand R, Taylor V. P., Oostelaar E., Beehan D. P., Paccamonti D. P., McDonnell S. M. (2014) Effect of contextually congruent stallion vocalization playback on intrauterine pressure in the mare. J. Equine Vet. Sci. 34, 131

Madill S., Troedsson M. H. T., Alexander S. L., Shand N., Santschi E. M., Irvine C. H. G. (2000) Simultaneous recording of pituitary oxytocin secretion and myometrial activity in estrous mares exposed to various breeding stimuli. J. Reprod. Fert. 56, 351-561

Madill S., Troedsson M. H. T., Santschi E. M., Malone E. D. (2002) Dose-response effect on intramuscular oxytocin treatment on myometrial contraction of reproductively normal mares during estrus. Theriogenology 58, 479-481

Marth C. D., Young N. D., Glenton L. Y., Noden D. M., Browning G. F., Krekeler N. (2015) Deep sequencing of the uterine immune response to bacteria during the equine estrous cycle. BMC Genomics 16, 934

Mattos R. C., Castillo L. F. F., Malschitzky E., Mattos R, Gregory R. M. (1999) Treatment of endometritis of experimentally infected mares. I. Effect of lavage, plasma and leukocytes on uterine bacterial challenge. Arq Fac Vet. - UFRGS 27, 49-60

Metcalf E. S. (2014) The effect of platelet-rich plasma (PRP) on intraluminal fluid and pregnancy rates in mares susceptible to persistent mating-induced endometritis. J. Equine Vet. Sci. 34, 128

Metcalf E. S., Scoggin K., Troedsson M. H. T. (2012) The effect of platelet-rich plasma on endometrial pro-inflammatory cytokines in susceptible mares following semen deposition. J. Equine Vet. Sci. 32, 498

Neves A. P., Keller A., Rodrigues-Trein C., Moller G., MascarenhasJobim M. I., Castilho L. F. F., de Itapema Cardoso M. R., Leibold W., Zerbe H., Klug E., Gregory R. M., Mattos R. C. (2007) Use of leukocytes as treatment for endometritis in mares experimentally infected with Streptococcus zooepidemicus. Anim. Reprod. Sci. 97, 314-322

Petersen M. R., Skive B., Christoffersen M., Lu K., Nielsen J. M., Troedsson M. H. T., Bojesen A. M. (2015) Activation of persistent Streptococcus equi subspecies zooepidemicus in mares with subclinical endometritis. Vet. Microbiol. 179, 119-125; DOI 10.1016/ivetmic 2015.06.006

Reghini M. F. S., Ramires Neto C., Sagabinazzi L. G., Chaves M. M. B., Dell'Aqua C., Busierre M. C. C., Dell'Aqua J. A., Papa F. O., Alvarenga M. A. (2016) Inflammatory response in chronic degenerative endometritis mares treated with platelet-rich plasma. Theriogenology 86, 516-522

Rogan D., Fumoso E.. Rodrigez E., Wade J., Sanchez-Bruni S. F. (2007) Use of mycobacterial cell wall extract (MCWE) in susceptible mares to clear experimentally induced endometritis with Streptococcus zooepidemicus. J. Equine Vet. Sci. 27, 112-117

Rohrbach B., Sheerin P., Steiner J., Matthews P., Cantrell C., Dodds L. (2006) Use of Proprionibacterium acne as adjunct therapy in treatment of persistent endometritis in the broodmare. Anim Reprod Sci. 94:259-60.

Rojer H, Aurich C. (2010) Treatment of persistent mating-induced endometritis in mares with the non-steroid anti-inflammatory drug vedaprofen. Reprod. Dom. Anim. 45, 458-460

Schramme A. R., Pinto C. R. F., Davies J., Whisnant C. S., Whiacre M. D. (2008) Pharmacokinetics of carbetocin, a long-acting analogue, following intravenous administration in horses. Equine Vet. J. $40,658-661$

Segabinazzi L. G., Friso A. M., Correal S. B., Crespilho A. M., DelI'Aqua J. A., Miro J., Papa F. O., Alvarenga M. A. (2017) Uterine clinical findings, fertility rate, leukocyte migration, and COX-2 protein levels in the endometrial tissue of susceptible mares treated with platelet-rich plasma before and after Al. Theriogenology $104,120-126$

Troedsson M. H. T. (1999) Uterine clearance and resistance to persistent endometritis in the mare. Theriogenology 52, 461-471

Troedsson M. H. T., Scott M., Liv I. K. M. (1995) Comparative treatment of mares susceptible to chronic uterine infection. Am. J. Vet. Res. 56, 468472

Troedsson M. H. T., Liv I. K. M., Ing M., Pascoe J. (2005) Smooth muscle electrical activity in the oviduct and the effect of oxytocin, PGF2 $a$ and PGE2 on the myometrium and oviduct of the cycling mare. In: Sharp D.C., Bazer F.W. (ed.) Biol. Repr. Mono. 1. Equine Reproduction VI, pp. 439-452.

Troedsson M. H. T., Ohlgren A. F., Ababneh M. M., Gregas M. (2001) Effect of periovulatory prostaglandin F2 on pregnancy rates and luteal function. Theriogenology 55, 1891-1899

Troedsson M. H. T., Woodward E. M. (2016) Our current understanding of the pathophysiology of equine endometritis with an emphasis on breeding-induced endometritis. Reprod. Biol. 16, 812; DOI 10.1016/i.repbio.2016.01.003.

Vandaele H., Daels P., Piepers S., LeBlanc M. M. (2008) The effect of post-insemination dexamethasone treatment on pregnancy rates in mares. Proceedings, The Havemeyer Foundation: The Chronically Infertile Mare. Hilton Head SC S. 43-44

Witte T. S., Melkus E., Walter I., Senge B., Schwab S., Aurich C., Heuwiser W. (2012) Effects of oral treatment with N-acetylcysteine on the viscosity of intrauterine mucus and endometrial function in estrus mares. Theriogenology 78, 1199-1208

Woodward E. M., Christoffersen M., Campos J., Betancourt A., Horohov D., Scoggin K. E., Squires E., Troedsson M. M. T. (2013) Endometrial inflammatory markers of the early immune response in mares susceptible or resistant to persistent breeding induced endometritis. Reprod. 145, 289-296

Woodward E. M., Christoffersen M., Campos J., Horohov D. W., Scoggin K. E., Squires E., Troedsson M. H. T. (2013) An investigation of uterine nitric oxide production in mares susceptible and resistant to persistent breeding induced endometritis, and the effects of immunomodulation. Reprod Dom Anim. 48, 554-614

Woodward E. M., Christoffersen M., Horohov D., Squires E. L., Troedsson M. H. T. (2014) The effect of treatment with immune modulators on endometrial cytokine expression in mares susceptible to persistent breeding induced endometritis. Equine Vet. J. 47, 235-239; DOI 10.1111/evj. 12266

Zerbe H., Castilho L. F.F., Engelke F., Mattos R. C., Schuberth H. J., Klug E. (2003) Isolation and cryopreservation of functionally competent equine leukocytes. J. Vet. Med. 50, 179-184

Zuin R., Palamidese A., Negrin R., Catozzo L., Scrada A., Balbinot M. (2005) High dose $\mathrm{N}$-acetylcysteine in patients with exacerbation of chronic obstructive pulmonary disease. Clin. Drug Invest. $25,401-408$ 